\title{
Aircraft pollution - a futuristic view
}

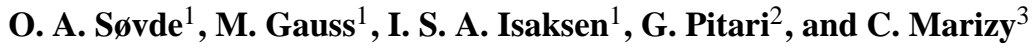 \\ ${ }^{1}$ Department of Geosciences, University of Oslo, Norway \\ ${ }^{2}$ Dipartimento di Fisica, University of L'Aquila, Italy \\ ${ }^{3}$ Airbus France, Acoustics \& Environment Department, Toulouse, France
}

Received: 2 February 2007 - Published in Atmos. Chem. Phys. Discuss.: 21 February 2007

Revised: 15 May 2007 - Accepted: 28 June 2007 - Published: 11 July 2007

\begin{abstract}
Impacts of $\mathrm{NO}_{\mathrm{x}}, \mathrm{H}_{2} \mathrm{O}$ and aerosol emissions from a projected 2050 aircraft fleet are investigated using the Oslo CTM2, with emissions provided through the EU project SCENIC. The aircraft emission scenarios consist of emissions from subsonic and supersonic aircraft. In particular it is shown that aerosol emissions from such an aircraft fleet can have a relatively large impact on ozone, and possibly reduce the total atmospheric $\mathrm{NO}_{\mathrm{x}}$ by more than what is emitted by aircraft. Without aerosol emissions this aircraft fleet leads to similar $\mathrm{NO}_{\mathrm{x}}$ increases for subsonic (at 11-12 km) and supersonic (at $18-20 \mathrm{~km}$ ) emissions, $1.35 \mathrm{ppbv}$ and $0.83 \mathrm{ppbv}$ as annual zonal means, respectively. $\mathrm{H}_{2} \mathrm{O}$ increases are also comparable at these altitudes: 630 and 599 ppbv, respectively. Tropospheric ozone increases are about $10 \mathrm{ppbv}$ in the Northern Hemisphere due to emissions from subsonic aircraft. Increased ozone loss from supersonic aircraft at higher altitudes leads to ozone reductions of about $39 \mathrm{ppbv}$ in the Northern Hemisphere and $22 \mathrm{ppbv}$ in the Southern Hemisphere. The latter reduction is a result of transport of ozone depleted air from northern latitudes. When including aircraft aerosol emissions, $\mathrm{NO}_{\mathrm{x}}$ is reduced due to heterogeneous chemistry. The reduced $\mathrm{NO}_{\mathrm{x}}$ seems to counterweight the reduction of ozone from emissions of $\mathrm{NO}_{\mathrm{x}}$ and $\mathrm{H}_{2} \mathrm{O}$ above $20 \mathrm{~km}$. At these altitudes the $\mathrm{NO}_{\mathrm{x}}$ (and thus ozone loss) reduction is large enough to give an aircraft emissions induced increase in ozone. In the height range $11-20 \mathrm{~km}$ altitude, however, ozone production is reduced. Heterogeneous reactions and reduced $\mathrm{NO}_{\mathrm{x}}$ enhances $\mathrm{ClO}$, further enhancing ozone loss in the lower stratosphere. This results in a $14 \mathrm{ppbv}$ additional reduction of ozone. Although supersonic aircraft have opposite effects on ozone in the upper and lower stratosphere, the change in ozone columns is clearly dominated by the upper stratospheric loss, thus supersonic aircraft aerosol emissions lead to enhanced ozone columns. The largest in-
\end{abstract}

Correspondence to: O. A. Søvde

(asovde@geo.uio.no) crease in the ozone column due to aerosol emissions is therefore seen in the Northern Hemispheric autumn and winter, giving a column increase of $4.5 \mathrm{DU}$. It is further found that at high northern latitudes during spring the heterogeneous chemistry on PSCs is particularly efficient, thereby increasing the ozone loss.

\section{Introduction}

Air traffic is continually increasing. According to the Global Market Forecast 2004-2023 (Airbus, 2004), revenue passenger kilometres will increase by $5.3 \%$ annually in this period, while freight tonne kilometres (air-freight) will increase by $5.9 \%$ annually. Although less fuel-efficient aircraft eventually will be replaced with new aircraft, the amount of burnt fuel will increase. A further increase in air traffic is assumed to take place after 2020, and by 2050 new high speed civil transport aircraft (so-called supersonic aircraft) are suggested to be developed to meet the demands for faster transport. While subsonic aircraft will have cruising altitudes up to about $12 \mathrm{~km}$, supersonic aircraft will fly up to altitudes of almost $20 \mathrm{~km}$. In the EU project SCENIC (Scenario of aircraft Emissions and Impact studies on Chemistry and climate, Rogers (2005)), several possible aircraft scenarios for 2050 were developed by Airbus (Rogers, 2005, and C. Marizy, personal communication), covering both commercial and non-commercial traffic.

Cruising at $16-18 \mathrm{~km}$ altitude, supersonic aircraft emissions mostly take place well above the tropopause, a region of more efficient accumulation of pollution. This is significantly different from subsonic traffic, with emissions often occurring in the upper troposphere, except for high latitudes where the lower stratospheric emissions are frequent.

Emissions from aircraft include ozone precursors (e.g. $\mathrm{NO}_{\mathrm{x}}$ ) and depleting substances (e.g. $\mathrm{H}_{2} \mathrm{O}$ ) as well as aerosol particles, which all affect atmospheric chemistry, e.g. ozone

Published by Copernicus Publications on behalf of the European Geosciences Union. 
production and destruction. Also components important for climate, $\mathrm{CO}_{2}$ in addition to $\mathrm{H}_{2} \mathrm{O}$ are emitted from aircraft. Several studies focusing on aircraft $\mathrm{NO}_{\mathrm{x}}$ emissions have been carried out (Johnston, 1971; Hidalgo and Crutzen, 1977; Johnson et al., 1992; Schumann, 1997; Dameris et al., 1998; Grewe et al., 2002; Gauss et al., 2006a), most of them addressing the impact of subsonic aircraft. The atmospheric impact of aircraft emissions has also been thoroughly addressed by e.g. Stolarski et al. (1995), Kawa et al. (1998) Fabian and Kärcher (1997), Brasseur et al. (1998), Isaksen (2003). This study is an extension of previous studies done within the EU projects TRADEOFF, CRYOPLANE and SCENIC. We focus on the atmospheric impact of a future fleet comprising sub- and supersonic aircraft (referred to as a "mixed fleet"). The adopted emissions of the mixed fleet include aerosol particles. In Sect. 2 the model setup and the emission scenarios are described, and in Sect. 3 the atmospheric impact of $\mathrm{NO}_{\mathrm{x}}$ and $\mathrm{H}_{2} \mathrm{O}$ aircraft emissions is presented. The impact of aerosol emissions from a mixed fleet is studied in Sect. 4, and discussion and conclusions are given in Sect. 5.

\section{Model description}

The Oslo CTM2 is a global chemical transport model. Advective transport is treated by the highly accurate and lowdiffusive Second Order Moments scheme (Prather, 1986), while the Tiedke mass flux scheme (Tiedke, 1989) is used for deep convection. Boundary layer mixing is treated according to the Holtslag K-profile scheme (Holtslag et al., 1990). The model includes comprehensive schemes for tropospheric and stratospheric chemistry, and comprises 98 species whereof 77 are transported. It is designed to study the upper troposphere and the lower stratosphere (UTLS), which is the region that cover the major cruising altitudes of aircraft. The numerical integration of chemical compounds is done applying the Quasi Steady State Approximation (QSSA) (Hesstvedt et al., 1978), with three different integration methods depending on the chemical lifetime of the species.

The meteorological data driving the Oslo CTM2 is taken from the European Centre for Medium-Range Weather Forecasts (ECMWF) operational Integrated Forecast System (using 4D-var assimilation) for the year 2000, and are forecasts produced with $12 \mathrm{~h}$ of spin-up starting from an analysis at noon on the previous day. The meteorological data are updated every third hour to ensure more realistic transport. The spectral resolution applied is $\mathrm{T} 21(5.6 \times 5.6$ degrees $)$ in 40 vertical layers, extending from the surface to $2 \mathrm{hPa}$ (pressure center of the top model layer at $10 \mathrm{hPa}$ ) in $\sigma$-pressure hybrid coordinates. The choice of horizontal resolution was made due to the large number of scenarios and the long spin-up time required for stratospheric studies, combined with the computational cost. Vertical model resolution in the UTLS varies between 0.8 and $1.2 \mathrm{~km}$, depending on latitude and season. At altitudes above $100 \mathrm{hPa}$ the vertical resolution is $20 \mathrm{hPa}$, corresponding to $\sim 2 \mathrm{~km}$ at $18 \mathrm{~km}$ altitude.

\subsection{Model performance}

With a focus on the tropospheric chemistry, the Oslo CTM2 has previously been tested and applied in various works (Berntsen and Isaksen, 1997; Grini et al., 2002; Brunner et al., 2003, 2005; Isaksen, 2003; Isaksen et al., 2005). The stratospheric chemistry module was originally developed by Stordal et al. (1985), and improved by adding heterogeneous chemistry to the scheme (Isaksen et al., 1990). The stratospheric chemistry was introduced in a stratospheric 3D CTM by Rummukainen et al. (1999), and later in the Oslo CTM2, which already included comprehensive tropospheric chemistry (Gauss, 2003). The model version with both tropospheric and stratospheric chemistry has previously been validated against measurements by satellites, sondes and lidar (Braathen et al., 2003), against satellite (Eskes, 2003; Brunner et al., 2005) and aircraft measurements (Isaksen, 2003). It is found to reproduce ozone measurements well. Further, the Oslo CTM2 has been used to study past and future changes in tropospheric and lower stratospheric ozone (Gauss et al., 2003c, 2006b) as input to studies of radiative forcing, and to study the impact of aircraft emissions of water vapor (Gauss et al., 2003b) and nitrogen oxides (Gauss et al., 2006a).

Recently the Oslo CTM2 (including stratospheric and tropospheric chemistry) has been improved by a new heterogeneous and microphysics scheme which is described by Søvde et al. (2007) ${ }^{1}$. It is found to reproduce ozone depletion events like the Ozone Hole and miniholes. An extensive evaluation of the Oslo CTM2 is also given by Søvde et al. $(2007)^{1}$, evaluating the model against aircraft, sonde and satellite measurements. Aircraft (Mozaic) flight measurements of ozone are found to be well reproduced on hourly basis for both T42 and T21 horizontal resolution, although T42 performed best. Furthermore, sonde and satellite measurements of ozone were reproduced well. The conditions where T21 performed significantly poorer than T42 was in Ozone Hole conditions where the averaging of polar grids cause too much diffusion across the polar vortex. Comparisons of the Oslo CTM2 with a number of vertical profiles from SAGE II for a standard 2000 run are shown for two latitude intervals $(30 \mathrm{~N}-45 \mathrm{~N}$ and $60 \mathrm{~N}-75 \mathrm{~N}$, respectively) in Figs. 1a and b. The modelled profiles are taken at the same hour and location (grid box value) as the measurements, showing that ozone is well reproduced in the UTLS. Due to the intermediate lifetime of ozone in the UTLS region, accurate transport as well as chemistry is needed to reproduce measurements. The evaluation of the Oslo CTM2 presented here shows that the Oslo CTM2 performs well.

\footnotetext{
${ }^{1}$ Søvde, O. A., Gauss, M., Smyshlyaev, S., and Isaksen, I. S. A.: The cold Arctic winter stratosphere of 2004/2005 - a Global Chemical Transport Model study, J. Geophys. Res., to be submitted, 2007.
} 
a.

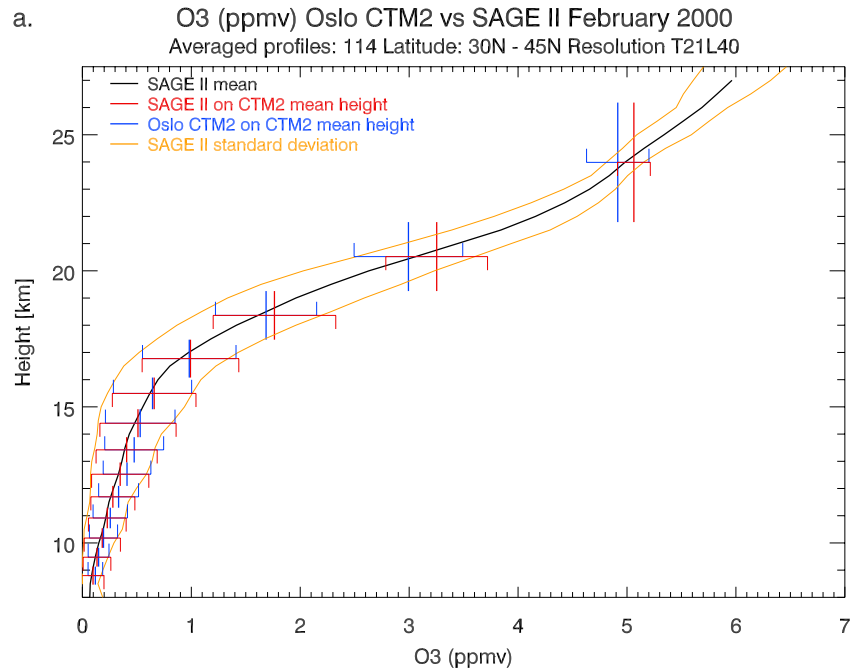

b. O3 (ppmv) Oslo CTM2 vs SAGE II July 2000

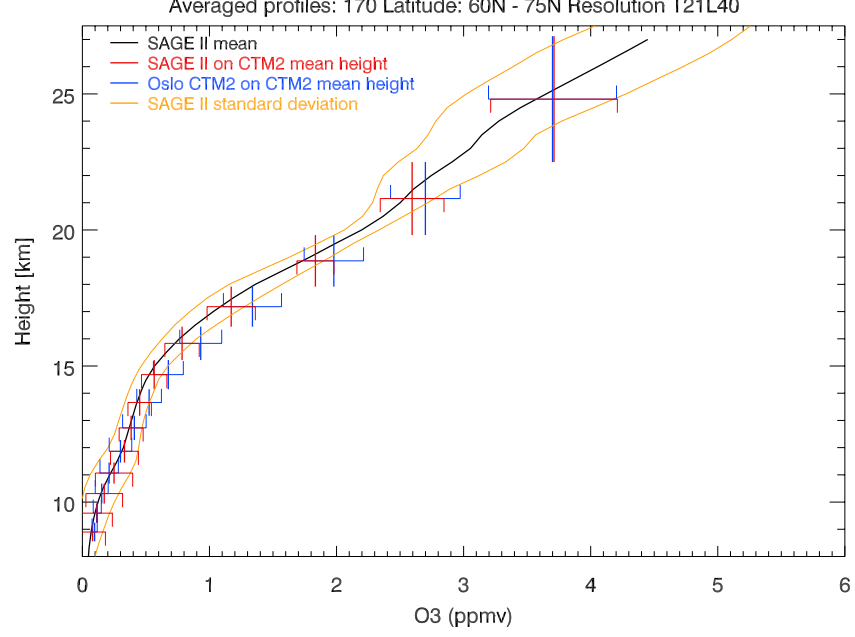

Fig. 1. Evaluation of Oslo CTM2 against SAGE II between 8 and $28 \mathrm{~km}$ altitude. Monthly mean ozone for (a) February 2000 between $30 \mathrm{~N}$ and $45 \mathrm{~N}$, and (b) July 2000 between $60 \mathrm{~N}$ and $75 \mathrm{~N}$. The average SAGE II ozone profile is given as the black line, and its standard deviations as the orange lines. The blue vertical lines are the Oslo CTM2 averages on each model level, and red is SAGE II averaged on the same model levels. Standard deviations are given as horizontal bars for each model level.

A parameter closely connected to transport and the Brewer-Dobson circulation is the age of stratospheric air (Hall and Plumb, 1994). Monge-Sanz et al. (2007) used the ECMWF operational (4D-var) data extending to $0.1 \mathrm{hPa}$. The age of air for was improved when forecasts on $3 \mathrm{~h}$ time resolution was used. For the 40-layer version of meteorological data applied here, we calculated the mean age of air from the age spectrum (according to Hall et al. (1999)), using the applied 2000 meteorology perpetually for 20 years, giving a zonal mean age maximum of 5.7 years at the top of the model domain (Fig. 2). The values at $20 \mathrm{~km}$ vary from 4.2 years at

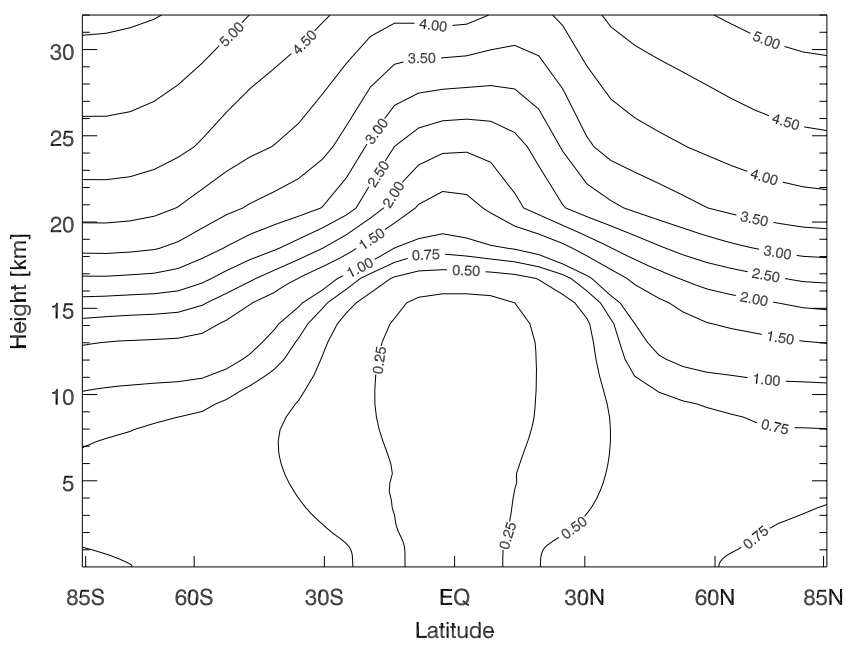

Fig. 2. Mean age of air for the Oslo CTM2 in T21 horizontal resolution, calculated using year 2000 meteorology. See text for details.

the South Pole to 1.3 in the tropics and 3.8 years at the North Pole, corresponding closely to the observed values shown by Monge-Sanz et al. (2007). Ideally the meteorological data should cover the whole stratosphere to assess the age of air. However, based on the calculated age presented here combined with the ability of reproducing measurements, we are confident that transport processes are well represented.

Our confidence is confirmed by looking at the longlived species, and in Fig. 3 the modelled annual mean $\mathrm{N}_{2} \mathrm{O}$ is compared to the UARS Reference Atmosphere Project climatology available from their web-site http://code916.gsfc.nasa. gov/. The main structure of the atmospheric circulation with upwelling in the tropics and subsidence at high latitudes is covered, as well as the $\mathrm{N}_{2} \mathrm{O}$ levels. Modelled gradients at low to mid latitudes above $20 \mathrm{~km}$ are somewhat underestimated, which is partly due to the coarse model vertical resolution at the highest altitudes, but also due to the upper boundary values, which are too low at low latitudes and too high at high latitudes. In this way reproduction of steep gradients observed is hindered by the boundary conditions, which prevents downward transport of low $\mathrm{N}_{2} \mathrm{O}$ at high latitudes. All in all, the model is reproducing measurements well.

\subsubsection{Emission set-up}

The natural and industrial emissions are taken from the EU project POET (Precursors of Ozone and their Effects in the Troposphere) (POET report, 1999). The model is set up to simulate the year 2050 according to the SCENIC project (Rogers, 2005), where the industrial emissions of $\mathrm{NO}_{\mathrm{x}}, \mathrm{CO}$ and volatile organic compounds (VOC) are scaled up from the year 2000 by $2.2,1.53$ and 1.55 , respectively. As the initial chemical conditions, we use a steady-state atmospheric composition from a calculation of a previous 2050 study, 

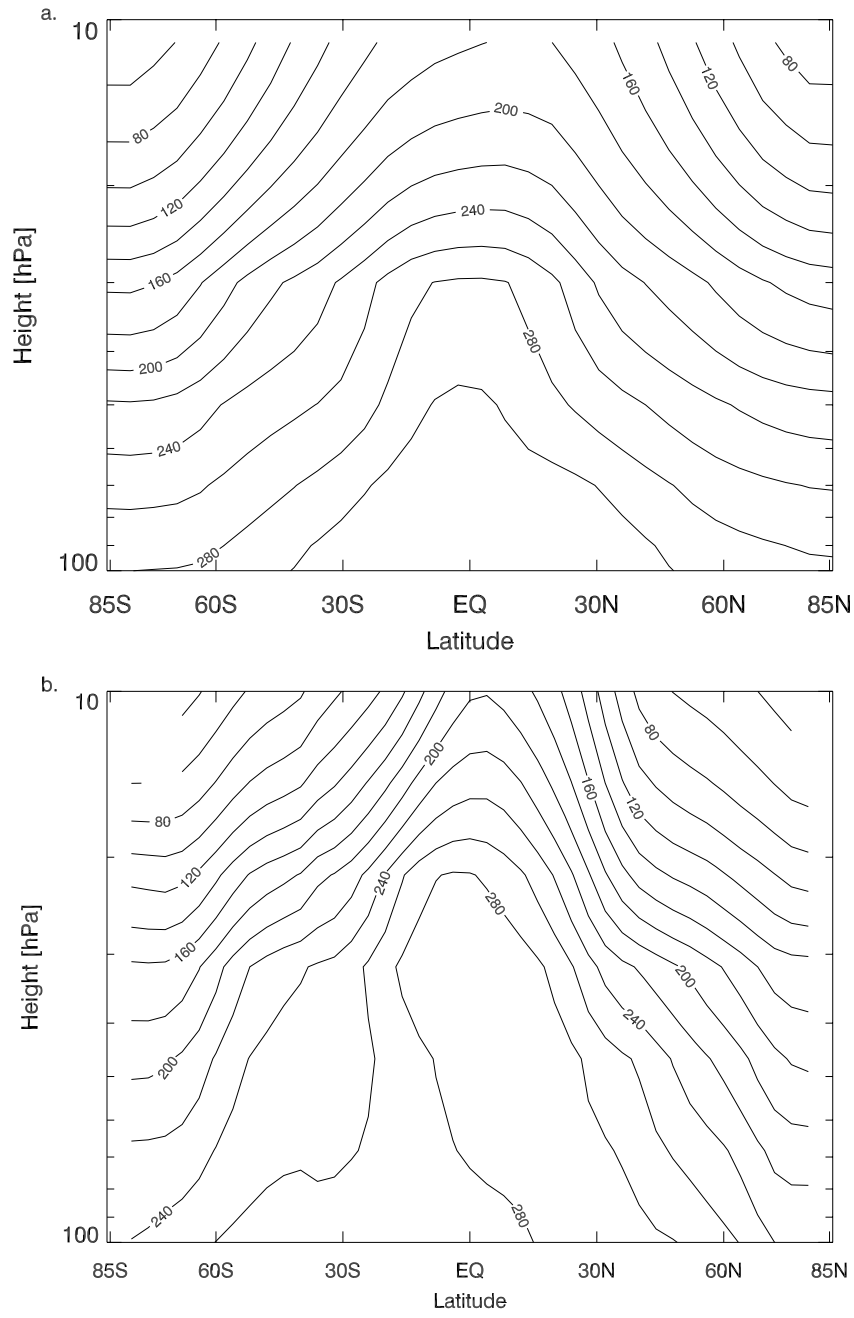

Fig. 3. Annual mean $\mathrm{N}_{2} \mathrm{O}$ from (a) the Oslo CTM2 and (b) the UARS Reference Atmosphere Project climatology.

with the same boundary conditions. The boundary conditions in both studies were based on World Meteorological Organization (2003) for longlived species (e.g. CFCs), and methane and $\mathrm{N}_{2} \mathrm{O}$ were set to 2549 ppbv and 372 ppbv, respectively, at the surface. Also emissions of stratospheric species were set to 2050 level, as were the model upper boundary conditions for all species (taken from the Oslo 2-D model (Stordal et al., 1985)). Otherwise, natural emissions are set to the level of year 2000. In the Oslo CTM2, tropospheric water vapor is retrieved from the meteorological data, while stratospheric water vapor is calculated assuming that the $\mathrm{H}_{2}$ content in water vapor, methane and hydrogen gas is constant $\left(\mathrm{H}_{\text {sum }}=\mathrm{H}_{2} \mathrm{O}+2 \mathrm{CH}_{4}+\mathrm{H}_{2}\right)$, where only $\mathrm{CH}_{4}$ is transported. $\mathrm{H}_{\text {sum }}$ is set to $8.598 \mathrm{ppmv}$ excluding aircraft emissions of $\mathrm{H}_{2} \mathrm{O}$. However, the $\mathrm{H}_{2} \mathrm{O}$ emitted from aircraft is transported as a separate species, which is superposed on this calculated value of $\mathrm{H}_{2} \mathrm{O}$. If PSC2 is formed, the solid $\mathrm{H}_{2} \mathrm{O}$ is calculated and removed from the gas phase, and we keep track of the sedimented amount of solid $\mathrm{H}_{2} \mathrm{O}$, thereby taking dehydration into account.

Starting from the initial conditions (the previous 2050 study), a spin-up of 7 years without aircraft emissions was performed, followed by additional six-year runs including each of the aircraft emission scenarios, where results from the last year of the simulations are presented here. The aircraft emission inventories studied in this work are listed in Table 1, and are given in 1x 1 degrees horizontal resolution and $305 \mathrm{~m}$ vertical resolution. These data are interpolated into the Oslo CTM2 grid each model time step. Due to the relatively coarse horizontal model resolution, a plume model is applied to the aircraft emissions (Kraabøl et al., 1999) to include the effects of in-plume chemistry, changing the $\mathrm{NO}_{\mathrm{x}}$ partitioning of the emissions. In this way the plume processed emissions can be emitted into the model grid.

Based on a predicted increase in non-commercial as well as commercial aircraft traffic, emissions from the most likely mixed fleet is given in MIX, assuming 501 supersonic aircraft and 114.1 million supersonic passengers per year and a supersonic aircraft cruise speed of 2.0 Mach. Aircraft emissions in this study include $\mathrm{NO}_{\mathrm{x}}$ and $\mathrm{H}_{2} \mathrm{O}$, omitting other products of fuel combustion such as $\mathrm{CO}_{2}, \mathrm{CO}$, different hydrocarbons and sulfur oxides; although $\mathrm{CO}_{2}$ is an important greenhouse gas, the lifetime is too long to distinguish the aircraft effect from other sources, and increases of the other combustion products are low compared to the background concentrations, hence they are expected to have a small atmospheric impact (Fabian and Kärcher, 1997). The aircraft emissions comprise commercial subsonic, commercial supersonic, general aviation and military fleet, and the respective emissions of $\mathrm{NO}_{\mathrm{x}}$ and $\mathrm{H}_{2} \mathrm{O}$ are listed in Table 2. $\mathrm{H}_{2} \mathrm{O}$ emissions are calculated as 1.25 of fuel burned.

$\mathrm{NO}_{\mathrm{x}}$ in the troposphere produces ozone in the presence of peroxy radicals and sunlight, while in the stratosphere it causes ozone depletion through the catalytic $\mathrm{NO}_{\mathrm{x}}$ cycle. $\mathrm{H}_{2} \mathrm{O}$ is an important source of the $\mathrm{OH}$ radical $\left(\mathrm{H}_{2} \mathrm{O}+\mathrm{O}^{1} \mathrm{D} \rightarrow 2 \mathrm{OH}\right)$, which contributes to ozone loss. In this study we focus on the total atmospheric impact of $\mathrm{NO}_{\mathrm{x}}$ and $\mathrm{H}_{2} \mathrm{O}$ emissions. Due to the high background concentration of $\mathrm{H}_{2} \mathrm{O}$ in the troposphere, the effects of $\mathrm{H}_{2} \mathrm{O}$ emissions in the troposphere are negligible. However, in the stratosphere $\mathrm{H}_{2} \mathrm{O}$ is very low, and therefore aircraft emissions have a larger effect on the $\mathrm{OH}$ formation.

Scenario AERO is similar to MIX, except that aircraft aerosol emissions are included. Aerosols offer surfaces for heterogeneous chemistry, which is important for $\mathrm{NO}_{\mathrm{x}}$ chemistry. The surface area density (SAD) of these aerosols was included in the model as a transported tracer with SADemissions calculated according to Danilin et al. (1998),

$\mathrm{SAD}=\frac{3 \mu_{f} \rho_{a} \xi \mathrm{EI}(\mathrm{S}) \mu_{\mathrm{H}_{2} \mathrm{SO}_{4}}}{r \rho_{s} w_{\mathrm{H}_{2} \mathrm{SO}_{4}} \mu_{S}}$ 
Table 1. The aircraft scenarios used in this study.

\begin{tabular}{clccc}
\hline Scenario & Fleet & $\begin{array}{c}\mathrm{NO}_{\mathrm{x}} \\
\text { emissions }\end{array}$ & $\begin{array}{c}\mathrm{H}_{2} \mathrm{O} \\
\text { emissions }\end{array}$ & $\begin{array}{c}\text { Aerosol } \\
\text { emissions }\end{array}$ \\
\hline noAC & No aircraft & no & no & no \\
MIX & Sub- and supersonic (mixed) fleet & \multicolumn{2}{c}{ See Table 2 } & no \\
AERO & MIX with aerosol emissions & as MIX & as MIX & yes \\
noH2O & MIX without $\mathrm{H}_{2} \mathrm{O}$ emissions & as MIX & no & no \\
noBACK & MIX without background aerosols & as MIX & as MIX & no \\
\hline
\end{tabular}

Table 2. The aircraft scenario emissions of the mixed fleet taken from Marizy et al. (2007)??.

\begin{tabular}{lccccc}
\hline Emitted species & \multicolumn{5}{c}{ Mixed fleet emissions 2050 } \\
\hline & Total & $\begin{array}{c}\text { Commercial } \\
\text { subsonic }\end{array}$ & $\begin{array}{c}\text { Commercial } \\
\text { supersonic }\end{array}$ & $\begin{array}{c}\text { General } \\
\text { aviation }\end{array}$ & $\begin{array}{c}\text { Military } \\
\text { aviation }\end{array}$ \\
\hline $\mathrm{NO}_{\mathrm{X}}\left(\mathrm{Tg}\left(\mathrm{NO}_{2}\right) / \mathrm{yr}\right.$ & 7.445 & 6.987 & 0.274 & 0.074 & 0.110 \\
$\mathrm{H}_{2} \mathrm{O}\left(\mathrm{Tg}\left(\mathrm{H}_{2} \mathrm{O}\right) / \mathrm{yr}\right.$ & 901.0 & 800.6 & 74.4 & 10.6 & 15.4 \\
Fuel burned $(\mathrm{Tg})$ & 720.8 & 640.5 & 59.5 & 8.5 & 12.3 \\
Aerosols & Calculated by Eq. (1), as described in the text. & \\
\hline
\end{tabular}

where $\rho_{s}=1.5 \mathrm{gcm}^{-3}$ is the density of sulfur, $\rho_{a}$ is the density of air, $w_{\mathrm{H}_{2} \mathrm{SO}_{4}}=50 \%$ is the weight percent of sulfuric acid and $\mu_{S}$ and $\mu_{\mathrm{H}_{2} \mathrm{SO}_{4}}$ are the molecular weights of sulfur and sulfuric acid, respectively. The particle radius is assumed to be $r=10 \mathrm{~nm}$, and the emission index of sulfur is $\mathrm{EI}(\mathrm{S})=4 \times 10^{-4}$. The fuel mixing ratio $\left(\mu_{f}\right)$ is calculated from the MIX $\mathrm{NO}_{\mathrm{x}}$ emissions applying the $\mathrm{EI}\left(\mathrm{NO}_{\mathrm{x}}\right)$ for supersonic aircraft $(4.6 \mathrm{~g} / \mathrm{kg})$. Even though subsonic aircraft have a higher emission index for $\mathrm{NO}_{\mathrm{x}}$ and may result in a too low SAD value for the subsonic flight levels, the application of the chosen emission index is justified by the uncertainty of $\mathrm{EI}(\mathrm{S})$ and the conversion factor $(\xi=0.05)$ of sulfur to sulfate, and the fact that the particles will be most important in the stratosphere. To simulate washout of emitted species, a method suggested by Danilin et al. (1998) is used, where emitted gases and aerosols are removed with e-folding time of 5 days below $400 \mathrm{hPa}$. In the top model layer, an e-folding time of 1 year is applied to simulate transport and mixing upwards. In this study, sedimentation of aircraft aerosols is not considered, but will be discussed in Sect. 5. Aircraft aerosol emissions are superimposed on the Oslo CTM2 background aerosols, which are taken from a monthly zonal mean SAD climatology derived from various satellite measurements, primarily SAGE II according to Thomason et al. (1997), and data for the year 1999 is applied. A sensitivity study of the MIX scenario without background aerosols (noBACK) is also carried out.

\section{Impact of emissions from a mixed fleet}

Subsonic and supersonic aircraft cruise at different altitudes. The subsonic fleet is larger than the supersonic fleet, giving the largest contribution to aircraft $\mathrm{NO}_{\mathrm{x}}$ emissions. This is clearly seen from Fig. 4, showing the annual zonal mean change in reactive nitrogen $\left(\mathrm{NO}_{\mathrm{y}}\right)$ with maximum increase at $11 \mathrm{~km}$, and a secondary maximum at about $18 \mathrm{~km}$. Clearly, the secondary maximum is due to supersonic aircraft, while the $11 \mathrm{~km}$ maximum is due to subsonic aircraft. The seasonal variation of the monthly zonal mean maximum due to subsonic aircraft ranges from 1.1 in September to $1.9 \mathrm{ppbv}$ in May (Fig. 5). During winter and spring, a larger fraction is emitted into the stratosphere than during summer months due to a lower tropopause, increasing the impact of subsonic aircraft. The higher tropopause in summer is accompanied by relatively strong convection, mixing and washout at midlatitudes, leading to a reduction in the $\mathrm{NO}_{\mathrm{y}}$ increases in the mid-latitude troposphere. This causes the maximum impact of aircraft emissions to shift northward (Kraabøl et al., 2002). A similar latitude shift of the maximum value is reported by Gauss et al. (2003a).

Although the contribution of supersonic aircraft to the zonal mean change is much smaller than for subsonic aircraft, the maximum $\mathrm{NO}_{\mathrm{y}}$ changes due to supersonic aircraft are locally comparable with subsonic aircraft emissions, especially in the summer months. Supersonic flights are confined mostly to the North Atlantic corridor, and this small zonal extent results in the slightly lower zonal mean maximum shown in Fig. 4. 


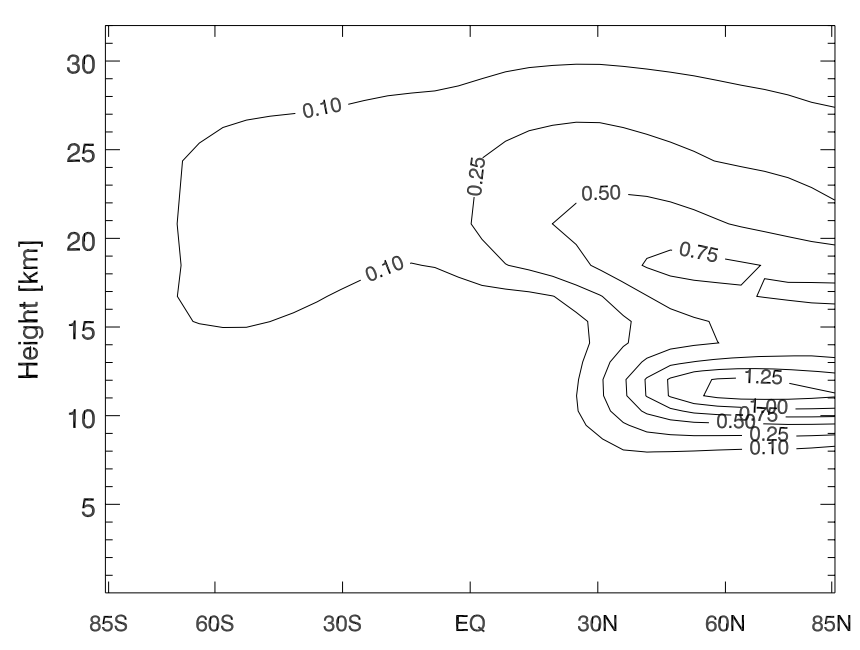

Fig. 4. Effect of mixed fleet aircraft emissions on $\mathrm{NO}_{\mathrm{y}}$, annual zonal mean (MIX minus noAC). Max: 1.35 ppbv.

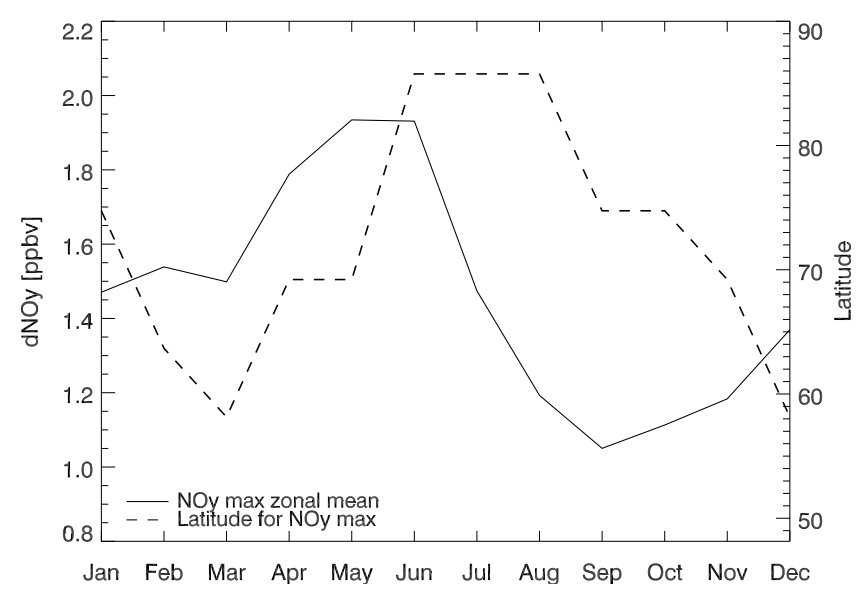

Fig. 5. Latitude and magnitude variation of the monthly mean maximum effect of aircraft emissions on $\mathrm{NO}_{\mathrm{y}}$ (MIX minus noAC): 1.1 to $1.9 \mathrm{ppbv}$.

Aircraft emissions of $\mathrm{H}_{2} \mathrm{O}$ contribute to an annual zonal mean increase of up to 624 ppbv above the background $\mathrm{H}_{2} \mathrm{O}$ (Fig. 6), ranging from 609 to $833 \mathrm{ppbv}$ in the monthly mean. The maximum change in monthly zonal mean $\mathrm{H}_{2} \mathrm{O}$ due to aircraft is mainly located at $11 \mathrm{~km}$ altitude, and is largest during summer when the maximum shifts to higher altitudes. As seen before, this shift is caused by higher tropopause levels extending transport and washout processes to higher altitudes.

The annual zonal mean effect of aircraft emissions $\left(\mathrm{NO}_{\mathrm{x}}\right.$ and $\mathrm{H}_{2} \mathrm{O}$ ) on ozone is given in Fig. 7, showing a maximum of $10 \mathrm{ppbv}$ at $10 \mathrm{~km}$ and a minimum of $-39 \mathrm{ppbv}$ at $24 \mathrm{~km}$. From month to month, these values vary from 7.2 to $18.4 \mathrm{ppbv}$ (corresponding to a change of 5.5 to $8.9 \%$ ) and

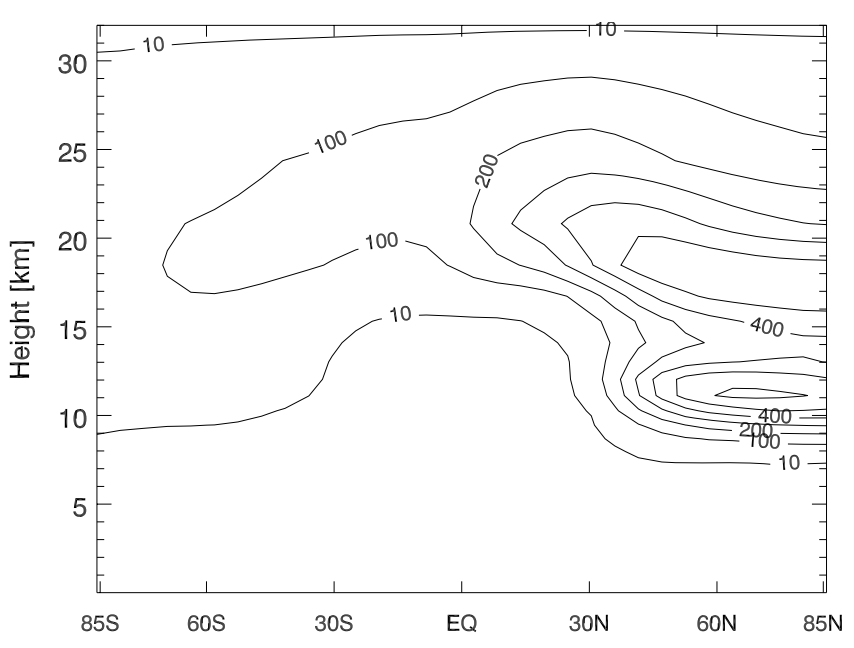

Fig. 6. Effect of aircraft emissions on $\mathrm{H}_{2} \mathrm{O}$, annual zonal mean (MIX minus noAC). Max: 629.69 ppbv.

from -48.8 to $-31.4 \mathrm{ppbv}(-1.8$ to $-0.8 \%)$, respectively (Fig. 8). The maximum variation largely follows the variation of the $\mathrm{NO}_{\mathrm{y}}$ maximum, but at an altitude of $9-10 \mathrm{~km}$. This means that the maximum ozone production is located at a lower altitude than the maximum of emissions. Unlike $\mathrm{NO}_{\mathrm{y}}$ and $\mathrm{NO}_{\mathrm{x}}$, the maximum ozone increase is shifted northwards for a longer time period in spring and summer, partly due to a higher tropopause and more washout processes at mid-latitudes. Also important for this shift is the increased amount of sunlight at high latitudes during spring and summer, causing more ozone production even for moderate $\mathrm{NO}_{\mathrm{x}}$ increases.

$\mathrm{NO}_{\mathrm{x}}$ contributes to ozone production in the presence of sunlight and peroxy radicals. At some altitude (the turn-over point), the amount of these radicals is too low for ozone production, and the catalytic $\mathrm{NO}_{\mathrm{x}}$ cycle takes over, reducing ozone. The zero line of Fig. 7 does not represent the turnover point, since transport processes also affect this figure: Downward transport of ozone depleted air will lower the altitude of the zero line. $\mathrm{H}_{2} \mathrm{O}$ emissions, however, contribute to ozone destruction at all altitudes through the $\mathrm{OH}$ chemistry. Looking at Fig. 8, the monthly variation of maximum ozone depletion due to aircraft resembles the variation of maximum production. The maximum depletion is located at about 30 $40 \mathrm{~N}$, around $24 \mathrm{~km}$, except during summer months, when a shifting northwards is seen, accompanied by a lowering of the maximum depletion to about $20 \mathrm{~km}$ altitude. This shift is due to stratospheric transport processes and more sunlight at higher latitudes. Being located above the $\mathrm{NO}_{\mathrm{x}}$ and $\mathrm{NO}_{\mathrm{y}}$ maxima, the maximum ozone depletion is caused by upward transport of $\mathrm{NO}_{\mathrm{x}}$ and $\mathrm{H}_{2} \mathrm{O}$, followed by more effective depletion at higher altitudes. Most of this ozone depletion is due to supersonic aircraft; only a small fraction originates from the upward transport of subsonic aircraft emissions. Mixing 


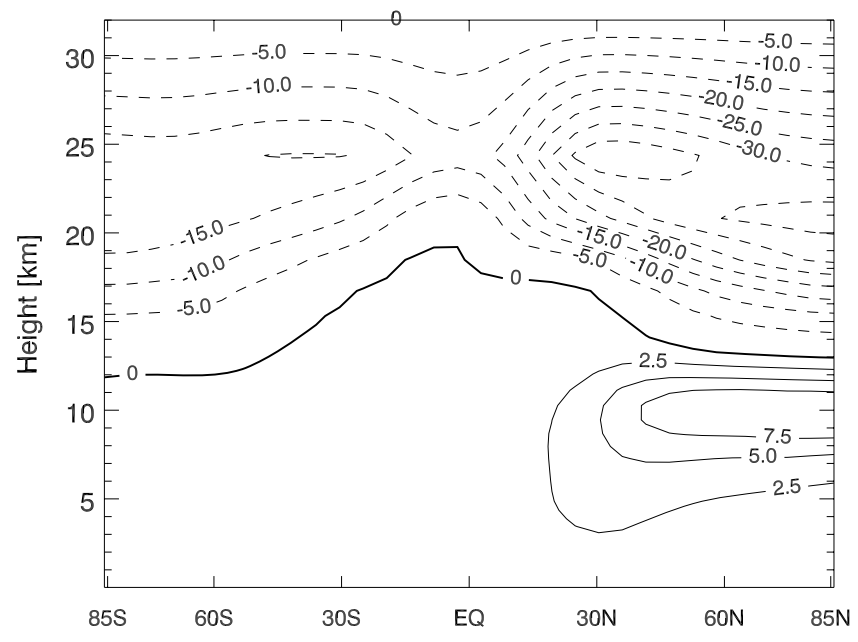

Fig. 7. Effect of aircraft emissions on $\mathrm{O}_{3}$, annual zonal mean (MIX minus noAC). Min: -39.24 ppbv, max: $9.96 \mathrm{ppbv}$.

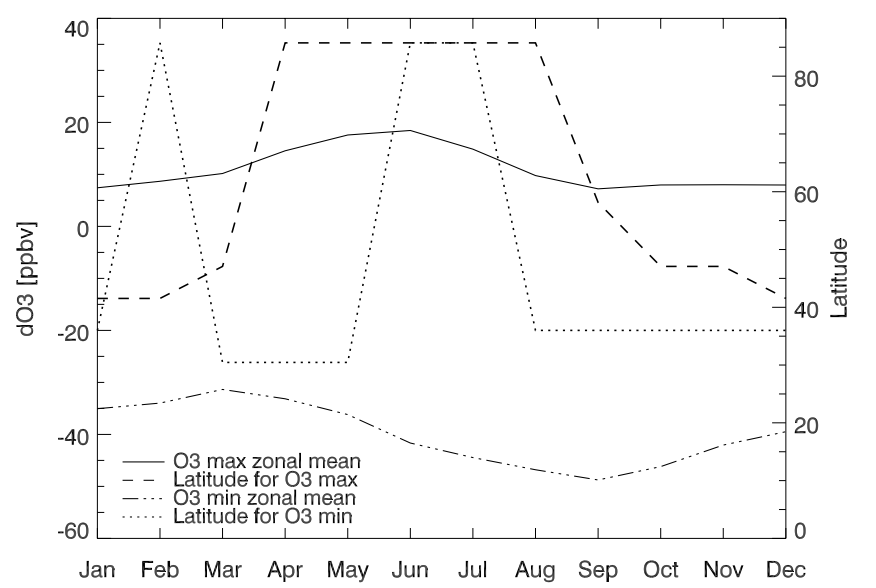

Fig. 8. Magnitude and latitude variation of the monthly zonal mean maximum/minimum effect of aircraft emissions on $\mathrm{O}_{3}$ (MIX minus noAC), maximum ranging from 7.2 to $18.4 \mathrm{ppbv}$ (due to subsonic aircraft) and minimum from -48.8 to $-31.4 \mathrm{ppbv}$ (due to supersonic aircraft).

of tropospheric (ozone increased) and stratospheric (depleted ozone) air in a mixed fleet scenario will therefore lower the tropospheric ozone increase due to subsonic aircraft.

Inter-hemispheric transport of stratospheric aircraft emissions is clearly seen in Figs. 4 and 6, in contrast to transport of subsonic aircraft emissions at lower altitudes, which is very limited (not shown). The high altitude transport will affect ozone in the Southern Hemisphere although emissions occur in the Northern Hemisphere.

When affecting ozone, aircraft emissions may also alter the total ozone column. The changes in daily zonal averages of the total ozone columns for the last two simulated years

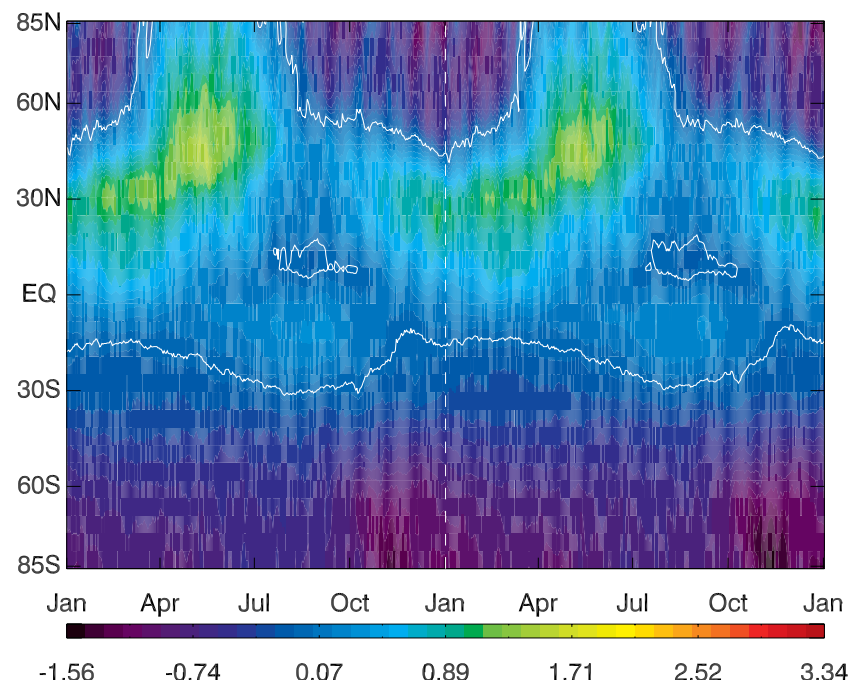

Fig. 9. Changes in the daily zonal mean total ozone column [Dobson Units] due to aircraft emissions (MIX minus noAC) for the last two years of simulation, ranging from $-1.56 \mathrm{DU}$ to $1.65 \mathrm{DU}$.

are shown in Fig. 9, ranging from $-1.56 \mathrm{DU}$ to $1.65 \mathrm{DU}$. The increase in the total column is located in the area of highest flight density. At higher latitudes, however, the supersonic aircraft contribute more to ozone loss, showing a net decrease in the total column, except during spring and summer months where the ozone production maximum is shifted northwards, overriding the ozone loss at higher altitudes. The ozone decrease in the Southern Hemisphere is mainly due to cross-hemispheric transport of emissions from supersonic aircraft, and to some extent transport of ozone depleted air. From August to October, there is also a decrease in total ozone in the tropical region. This is because the tropospheric ozone production due to aircraft emissions is small due to a high tropopause and increased washout of $\mathrm{NO}_{\mathrm{y}}$ during these months, causing the stratospheric depletion to dominate.

A sensitivity study omitting aircraft emissions of $\mathrm{H}_{2} \mathrm{O}$ (scenario noH2O) reveals that ozone changes due to aircraft emissions are mainly caused by $\mathrm{NO}_{\mathrm{x}}$. This is carried out looking at the MIX - noH2O difference. Emissions of $\mathrm{H}_{2} \mathrm{O}$ give maximum ozone losses ranging from 6.7 to $11.4 \mathrm{ppbv}$ in the monthly zonal mean (not shown). The maximum effect of $\mathrm{H}_{2} \mathrm{O}$ on ozone is generally located at $25-30 \mathrm{~N}$ and $24 \mathrm{~km}$ height with values ranging from 6 to $7 \mathrm{ppbv}$. However, the largest decrease in ozone is found in October-November due to PSC chemistry taking place at about $18 \mathrm{~km}$ at the South Pole. The ozone reduction due to aircraft emissions of $\mathrm{H}_{2} \mathrm{O}$ is most prominent in the stratosphere, although there is some ozone reduction caused by $\mathrm{H}_{2} \mathrm{O}$ in the troposphere. At the highest latitudes around $24 \mathrm{~km}$ altitude and during summer, $\mathrm{H}_{2} \mathrm{O}$ emissions slightly enhance heterogeneous chemistry on background aerosols, reducing $\mathrm{NO}_{\mathrm{x}}$ and thereby increasing ozone. 


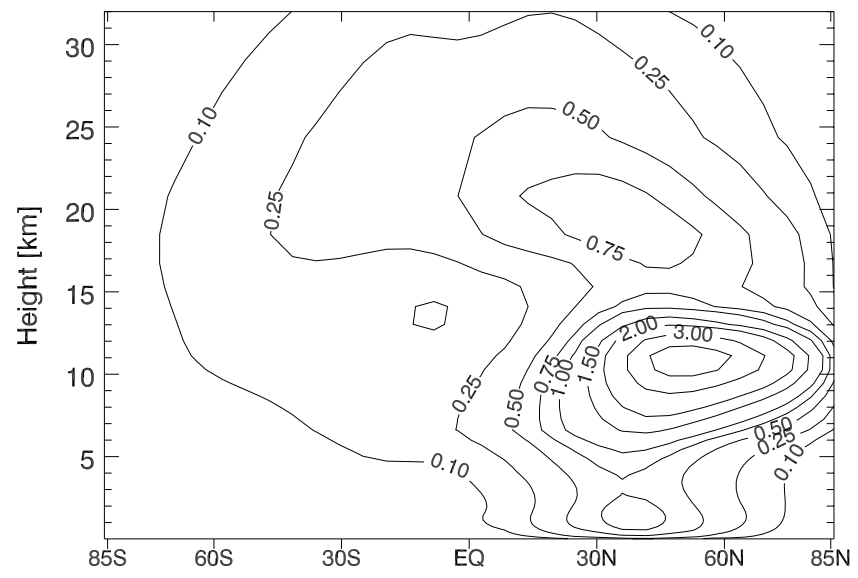

Fig. 10. Annual zonal mean of aircraft aerosol surface area density from the mixed fleet. Max: $4.7 \mu \mathrm{m}^{2} \mathrm{~cm}^{-3}$.

\section{Impact of aerosol emissions from a mixed fleet}

Heterogeneous reactions may take place on sulfate aerosols converting $\mathrm{NO}_{\mathrm{x}}$ into $\mathrm{HNO}_{3}$ - reactions being most effective at low temperatures. Depending on the altitude of this conversion, the resulting reductions of $\mathrm{NO}_{\mathrm{x}}$ will either reduce the production of ozone in the troposphere and lowermost stratosphere, or reduce the loss at higher altitudes. However, the formation of PSCs and chlorine activation may be enhanced by a reduction of $\mathrm{NO}_{\mathrm{x}}$.

Calculating the aircraft aerosol SAD emissions based on the method of Danilin et al. (1998), we find an annual zonal average SAD maximum of $4.7 \mu \mathrm{m}^{2} / \mathrm{cm}^{3}$ (Fig. 10), the monthly zonal mean maximum varying steadily through the year (Fig. 11), ranging from $3.8 \mu \mathrm{m}^{2} / \mathrm{cm}^{3}$ in September to $6.2 \mu \mathrm{m}^{2} / \mathrm{cm}^{3}$ in May. As for $\mathrm{NO}_{\mathrm{y}}$ emissions, the largest values are found in the Northern Hemispheric winter and spring at about $47 \mathrm{~N}$ and $11 \mathrm{~km}$ height, also shifting slightly to the north during summer and autumn because of the meteorological conditions. Although the maximum value decreases during summer conditions, the surface area density values in the stratosphere increase due to upward transport. The tropospheric reduction of $\mathrm{NO}_{\mathrm{x}}$ due to aerosol emissions is largest in spring, while the stratospheric reduction is largest in autumn. Hence, the largest reduction of ozone production due to aerosol emissions from aircraft occurs during spring, while the largest reduction of ozone loss at higher altitudes takes place in autumn.

The heterogeneous conversion of $\mathrm{NO}_{\mathrm{x}}$ to $\mathrm{HNO}_{3}$ will also occur on background aerosols, similarly affecting the production and loss of ozone. In Fig. 12 we see the annual zonal mean effect of aircraft aerosol emissions on ozone (AERO - MIX), superimposed on the effect of background aerosols (MIX - noBACK), for latitudes between 30 and 60 degrees in (a) the Northern and (b) Southern Hemisphere. Most promi-

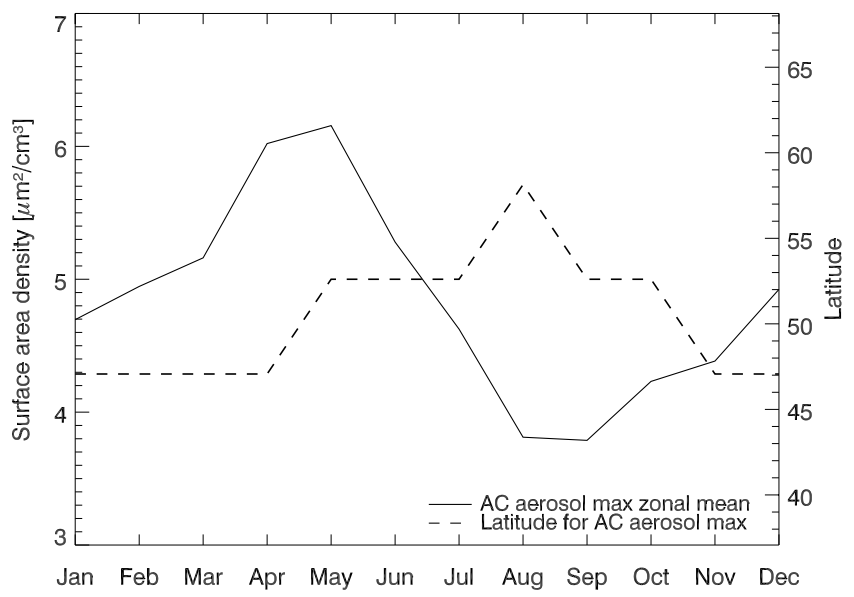

Fig. 11. Variation of the magnitude and latitude of the monthly zonal mean maximum of aircraft aerosol surface area density.

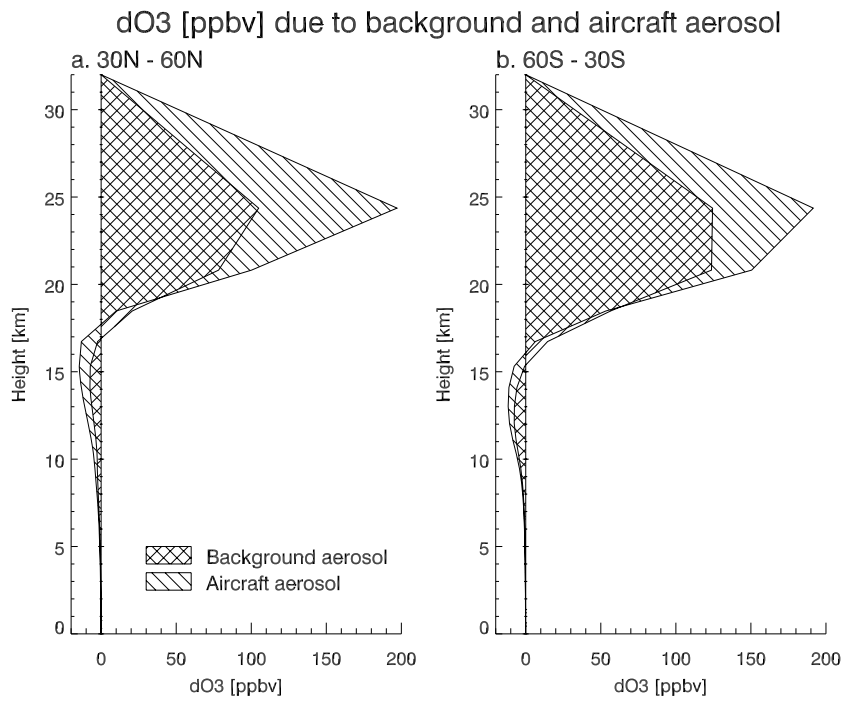

Fig. 12. Annual zonal mean effect of background aerosol on $\mathrm{O}_{3}$ (cross-hatched) and the contribution from aircraft aerosol emissions (hatched). (a): $30 \mathrm{~N}-60 \mathrm{~N}$, (b): $60 \mathrm{~S}-30 \mathrm{~S}$ (given in ppbv).

nent is the increase in ozone between 18 and $30 \mathrm{~km}$ due to ozone loss reduction, where the effect of aircraft aerosols is comparable with the background aerosols. For altitudes between 12 and $20 \mathrm{~km}$ aircraft aerosols contribute to an ozone reduction through reduced production and a slight increase in ozone loss due to more PSCs or supercooled ternary solutions (STS).

The amount of PSCs is dependent on $\mathrm{HNO}_{3}$ and $\mathrm{H}_{2} \mathrm{SO}_{4}$, where the latter is calculated from the amount of background aerosols available (described by Søvde et al., $2007^{1}$ ). Thus an increase in $\mathrm{HNO}_{3}$ and $\mathrm{H}_{2} \mathrm{SO}_{4}$ due to aircraft aerosol emissions leads to a slight increase of PSCs and therefore an 


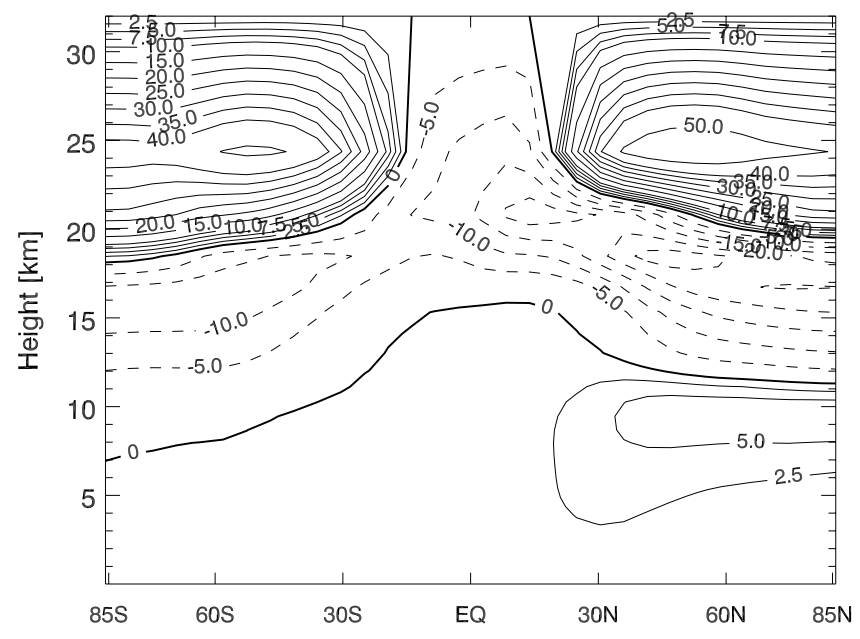

Fig. 13. Annual zonal mean effect of a mixed fleet with aerosol emissions on $\mathrm{O}_{3}$ (AERO minus noAC), given in ppbv.

increase in ozone loss. Also, a reduction in $\mathrm{NO}_{\mathrm{x}}$ will result in more active chlorine available for depleting ozone. These effects are apparent at altitudes between 12 and $20 \mathrm{~km}$.

The maximum increase of ozone for a mixed fleet including aerosol emissions (Fig. 12), has a larger magnitude than the maximum decrease due to $\mathrm{NO}_{\mathrm{x}}$ and $\mathrm{H}_{2} \mathrm{O}$ emissions only (Fig. 7). Aircraft aerosols give a reduction of $\mathrm{NO}_{\mathrm{x}}$ through heterogeneous reactions, reducing the loss of ozone due to the $\mathrm{NO}_{\mathrm{x}}$ cycle. The increase in aerosol SAD also intensify the heterogeneous conversions, lowering the concentration of $\mathrm{HCl}$ and thus the heterogeneous loss of $\mathrm{ClONO}_{2}$. In this way more $\mathrm{NO}_{\mathrm{x}}$ is bound up in $\mathrm{ClONO}_{2}$, while also the $\mathrm{ClO}$ is increased, since less $\mathrm{NO}_{2}$ is available for forming $\mathrm{ClONO}_{2}$. The same applies for $\mathrm{BrO} / \mathrm{BrONO}_{2}$. Both $\mathrm{NO}_{\mathrm{x}}$ and $\mathrm{ClO}$ are responsible for ozone loss, so by looking at the effect on ozone (AERO - noAC, Fig. 13) we see that above $18-20 \mathrm{~km}$ the $\mathrm{NO}_{\mathrm{x}}$ cycle is more important for ozone than the $\mathrm{ClO}$ - giving an increase of ozone due to reduced $\mathrm{NO}_{\mathrm{x}}$. From $18-20 \mathrm{~km}$ and down to about $11-12 \mathrm{~km}$ (lower at the Southern Hemisphere), the turn-over point where $\mathrm{NO}_{\mathrm{x}}$ starts to produce ozone will be reached. However, in this region enhanced $\mathrm{ClO}$ and $\mathrm{BrO}$ increase the ozone loss in addition to the reduced ozone production due to lower $\mathrm{NO}_{\mathrm{x}}$. Below $11-12 \mathrm{~km}$ the $\mathrm{NO}_{\mathrm{x}}$ reduction due to aerosols is not large enough to overcome the aircraft emissions of $\mathrm{NO}_{\mathrm{x}}$, resulting in increased ozone production there (Fig. 13). Therefore, a mixed fleet with aerosol emissions results in an increase in the daily zonal mean total column at most latitudes (Fig. 14; AERO minus noAC). At the lowermost latitudes through the year, and at the highest latitudes during summer, the reduced ozone production and enhanced loss due to $\mathrm{ClO}$ cause a decrease in ozone. The ozone column reduction at high latitudes during spring is due to increased heterogeneous chemistry on PSCs and therefore increased ozone loss due to $\mathrm{ClO}$.

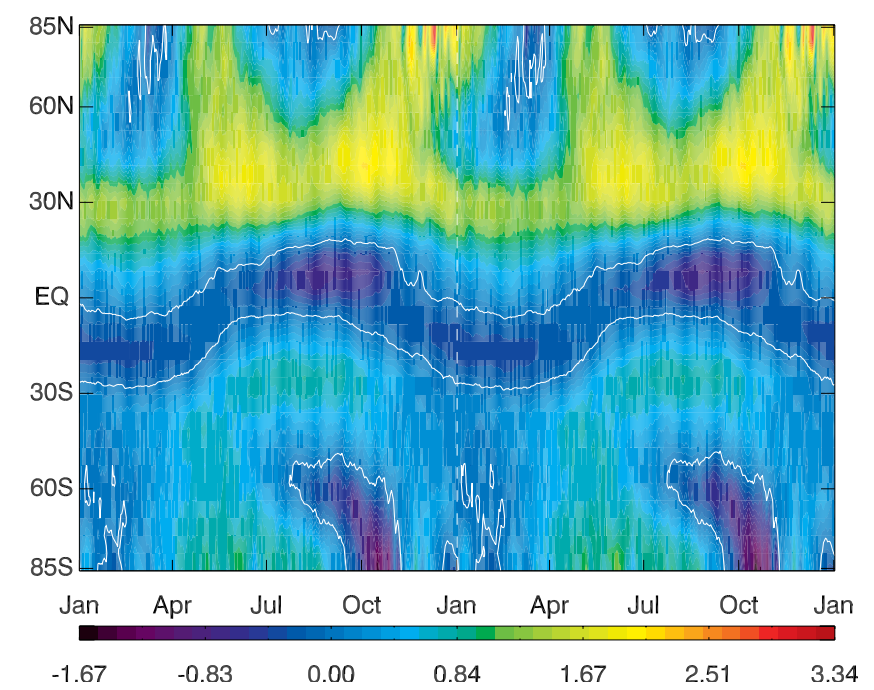

Fig. 14. Changes in the daily zonal mean total ozone column [Dobson Units] due to the mixed fleet aircraft emissions including aerosol emissions (AERO minus noAC), for the last two years of simulations, ranging from $-1.67 \mathrm{DU}$ to $3.34 \mathrm{DU}$.

Separating the effect of aircraft aerosols, by comparing the AERO scenario to the mixed fleet scenario (MIX), aircraft aerosols reduces the total ozone column in spring, and increase it in autumn (Fig. 15). Again, the decrease is due to reduced ozone production below the turn-over point (about $20 \mathrm{~km}$ ), combined with increased ozone loss by $\mathrm{ClO}$ and due to heterogeneous reactions on PSCs/STS. The increase is due to ozone loss decrease at higher altitudes (Fig. 16). The decrease in ozone column near the North Pole during May through June is due to more ozone loss below $20 \mathrm{~km}$ (due to $\mathrm{ClO}$ increase and reduced ozone production) than the ozone loss is decreased above $20 \mathrm{~km}$ (due to $\mathrm{NO}_{\mathrm{x}}$ ). Aerosols are also transported into the Southern Hemisphere, readily reducing $\mathrm{NO}_{\mathrm{x}}$ there as well, giving similar results, however smaller in magnitude. The cross-hemispheric transport is most effective above $18 \mathrm{~km}$, mainly resulting in reduced ozone loss. However, $\mathrm{ClO}$ is also increased here, to some extent enhancing the ozone loss below $18 \mathrm{~km}$. The ozone loss is also increased in spring when heterogeneous chemistry on PSCs/STS is enhanced, increasing the Ozone Hole depth.

Stratospheric $\mathrm{H}_{2} \mathrm{O}$ increases slightly due to the presence of aircraft aerosols (not shown), with an annual zonal mean maximum increase after six years of $7.3 \mathrm{ppbv}$. This is due to heterogeneous reactions on the aerosols, leading to $\mathrm{H}_{2} \mathrm{O}$ production from methane: Because the stratospheric $\mathrm{H}_{2} \mathrm{O}$ in the model is calculated assuming constant total hydrogen, a decrease in methane will increase the amount of $\mathrm{H}_{2} \mathrm{O}$. 


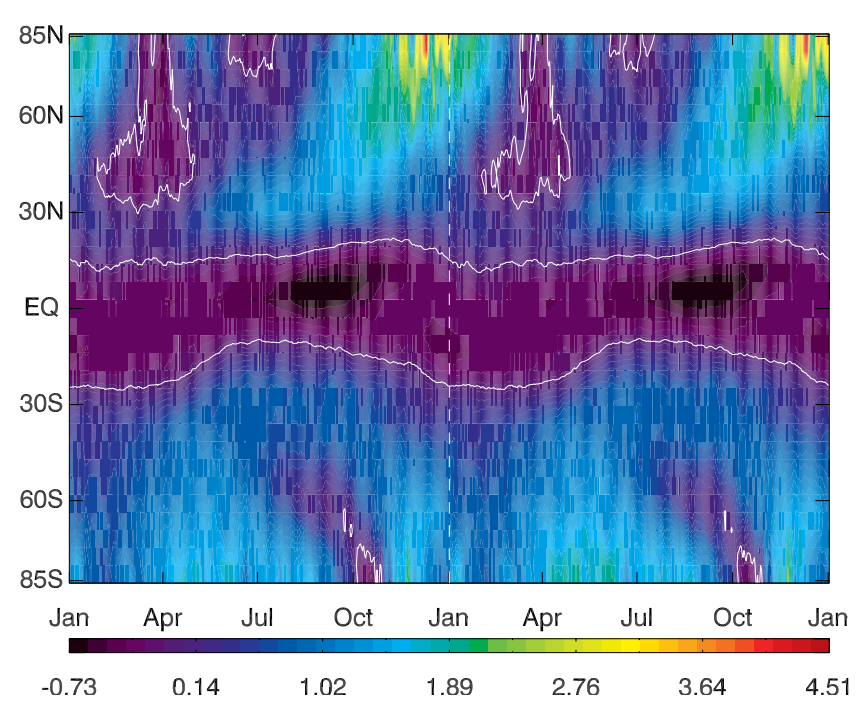

Fig. 15. Changes in the daily zonal mean total ozone column [Dobson Units] due to the mixed fleet aerosol emissions (AERO minus MIX), for the last two years of simulations, ranging from $-0.73 \mathrm{DU}$ to $4.51 \mathrm{DU}$.

\section{Discussion and conclusions}

We have shown that aerosol emissions in a projected future (2050) "mixed fleet" of subsonic and supersonic aircraft are likely to increase stratospheric ozone due to a lowered loss to $\mathrm{NO}_{\mathrm{x}}$, leading to an increase in the total ozone column. Without aerosol emissions, subsonic aircraft are found to increase tropospheric ozone and lower stratospheric ozone in agreement with previous studies, although with a larger impact ( 7 to 18 ppbv ozone increase in the monthly zonal mean) compared to previous studies of present impact ( 3 to 8 ppbv; Gauss et al., 2006a). Similarly, supersonic aircraft are estimated to give ozone depletion in the stratosphere (31 to $49 \mathrm{ppbv}$ as monthly zonal mean). A mixed fleet will therefore reduce the total ozone column compared to a subsonic fleet. Reduced stratospheric ozone in the Southern Hemisphere is a result of cross hemispheric transport of ozone depleted air. At northern high latitudes, aircraft emissions cause an increase in the total ozone column in spring and early summer - when transport processes and the amount of sunlight increase the ozone production - and a decrease in autumn.

The maximum contribution of $\mathrm{H}_{2} \mathrm{O}$ emissions from a mixed fleet to stratospheric ozone depletion ranges from 6.7 to $11.4 \mathrm{ppbv}$ in the monthly zonal mean. The largest effect is found to occur through heterogeneous chemistry in October and November.

When aircraft aerosol emissions are introduced, $\mathrm{NO}_{\mathrm{x}}$ levels are reduced due to heterogeneous chemistry, while $\mathrm{ClO}$ levels increase. This results in enhanced ozone loss in the 11-20 km region. To some extent aircraft aerosols will also

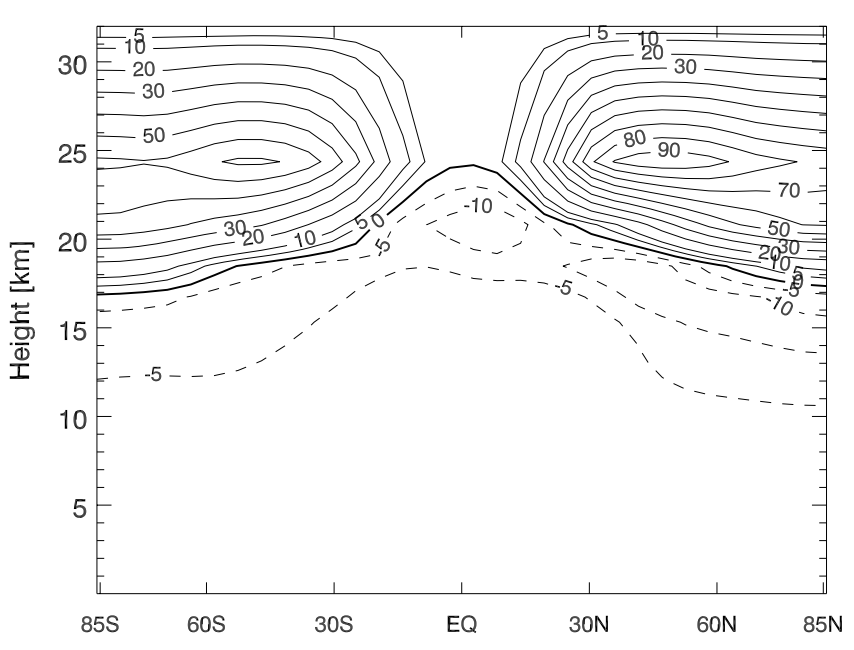

Fig. 16. Annual zonal mean effect of aircraft aerosol emissions on $\mathrm{O}_{3}$ (AERO minus MIX), given in ppbv.

reduce tropospheric $\mathrm{NO}_{\mathrm{x}}$ and therefore ozone production, contributing to a reduction of the total ozone column. The heterogeneous chemistry and the lowered production contributes to a reduction in the total ozone column, whereas the stratospheric $\mathrm{NO}_{\mathrm{x}}$ reduction contribute to an ozone column increase.

An increase in the surface area density of aerosols converts more $\mathrm{NO}_{\mathrm{x}}$ to $\mathrm{HNO}_{3}$ and the reduction of $\mathrm{NO}_{\mathrm{x}}$ activates more chlorine, and increase ozone loss due to PSCs. Background aerosols at kept at the low 1999 level. Increases in the background aerosols increase, e.g. due to volcanic eruptions, will affect $\mathrm{NO}_{\mathrm{x}}$ and the ozone loss. Likewise, adopting the 2000 meteorology as a reference for this study to ensure stable steady-state results, could have an impact on the calculated perturbations. The year 2000 has been reported to exhibit a cold bias near the tropopause (Randel et al., 2004). In a too cold UTLS region the heterogeneous conversions would be overestimated which would lead to a smaller $\mathrm{O}_{3}$ loss due to $\mathrm{NO}_{\mathrm{x}}$ and larger loss due to halogens. In respect to this, the 2000 UTLS could be more similar to year 2050 conditions with increased $\mathrm{CO}_{2}$ levels. Assessing the impact of meteorology on the chemical perturbations in the UTLS region is being done in another study.

Although T21 reproduces the main features of measurements, it is a rather coarse horizontal resolution. We find it sufficient for this study, combined with the applied aircraft plume model. Increasing the resolution to T42 will be done in the future, as well as increasing the vertical resolution to cover the whole stratosphere.

It should be noted that we have assumed no sedimentation of aircraft aerosols. If included, the effect of the calculated aerosol surface area density would probably be somewhat reduced, with the result that the ozone reduction due to lowered $\mathrm{NO}_{\mathrm{x}}$ and increased $\mathrm{ClO}$ would be smaller, possibly 
resulting in a decrease in the total ozone column. Nevertheless, aircraft aerosol emissions seem to be an important part of the stratospheric aircraft emissions.

Edited by: W. Collins

\section{References}

Airbus: Global Market Forecast 2004-2023, Published at the Airbus S.A.S. website, http://www.airbus.com/, 2004.

Berntsen, T. and Isaksen, I. S. A.: A global 3-D chemical transport model for the troposphere, 1, Model description and CO and Ozone results, J. Geophys. Res., 102, 21 239-21 280, doi:10.1029/97JD01140, 1997.

Braathen, G., Arlander, B., Dahlback, A., Edvardsen, K., Engelsen, O., Fløisand, I., Gauss, M., Hansen, G., Hoppe, U.-P., Høiskar, B. A. K., Isaksen, I., Kjeldstad, B., Kylling, A., Orsolini, Y., Rognerud, B., Stordal, F., Sundet, J., Thorseth, T. M., and Tørnkvist, K. K.: COSUV, third annual report, Norwegian institute for air research (NILU), http://www.nilu.no/projects/cozuv/, 2003.

Brasseur, G. P., Cox, R. A., Hauglustaine, D., Isaksen, I., Lelieveld, J., Lister, D. H., Sausen, R., Schumann, U., Wahner, A., and Wiesen, P.: European scientific assessment of the atmospheric effects of aircraft emissions, Atmos. Environ., 32, 2329-2418, doi:10.1016/S1352-2310(97)00486-X, 1998.

Brunner, D., Staehelin, J., Rogers, H. L., Köhler, M. O., Pyle, J. A., Hauglustaine, D., Jourdain, L., Berntsen, T. K., Gauss, M., Isaksen, I. S. A., Meijer, E., van Velthoven, P., Pitari, G., Mancini, E., Grewe, V., and Sausen, R.: An evaluation of the performance of chemistry transport models by comparison with research aircraft observations. Part 1: Concepts and overall model performance, Atmos. Chem. Phys., 3, 1609-1631, 2003,

http://www.atmos-chem-phys.net/3/1609/2003/.

Brunner, D., Staehelin, J., Rogers, H. L., Köhler, M. O., Pyle, J. A., Hauglustaine, D. A., Jourdain, L., Berntsen, T. K., Gauss, M., Isaksen, I. S. A., Meijer, E., van Velthoven, P., Pitari, G., Mancini, E., Grewe, V., and Sausen, R.: An evaluation of the performance of chemistry transport models - Part 2: Detailed comparison with two selected campaigns, Atmos. Chem. Phys., 5, 107-129, 2005, http://www.atmos-chem-phys.net/5/107/2005/.

Dameris, M., Grewe, V., Köhler, I., Sausen, R., Brhl, C., Groo, J.-U., and Steil, B.: Impact of aircraft NOx emissions on tropospheric and stratospheric ozone. part II: 3-D model results, Atmos. Environ., 32, 3185-3199, doi:10.1016/S13522310(97)00505-0, 1998.

Danilin, M. Y., Fahey, D. W., Schumann, U., Prather, M. J., Penner, J. E., Ko, M. K. W., Weisenstein, D. K., Jackman, C. H., Pitari, G., Köhler, I., Sausen, R., Weaver, C. J., Douglass, A. R., Connell, P. S., Kinnison, D. E., Dentener, F. J., Fleming, E. L., Berntsen, T. K., Isaksen, I. S. A., Haywood, J. M., and Kärcher, B.: Aviation fuel tracer simulation: Model intercomparison and implications, Geophys. Res. Lett., 25, 3947, doi:10.1029/1998GL900058, 1998.

Eskes, H. E. A.: The EU project GOA - GOME Assimilated and Validated Ozone NO2 Fields for Scientific Users and for Model
Validation, Project Final report, project Final Report, Contract No. EVK2-CT-2000-00062, 2003.

Fabian, P. and Kärcher, B.: The Impact of Aviation upon the Atmosphere, Physics and Chemistry of The Earth, 22, 503-598, doi:10.1016/S0079-1946(97)00181-X, 1997.

Gauss, M.: Impact of aircraft emissions and ozone changes in the 21st century: 3-D model studies, Ph.D. thesis, University of Oslo, Department of Geophysics, Section of Meteorology and Oceanography, PB. 1022 Blindern, 0315 Oslo, Norway, iSSN 1501-7710, No. 304, 2003.

Gauss, M., Isaksen, I. S. A., Lee, D., and Søvde, A.: Present and future impact of aircraft NOx emissions on the atmosphere - Tradeoffs to reduce the impact, Institute report series, 123, department of Geosciences, University of Oslo, Oslo, Norway, 2003a.

Gauss, M., Isaksen, I. S. A., Wong, S., and Wang, W. C.: Impact of $\mathrm{H} 2 \mathrm{O}$ emissions from cryoplanes and kerosene aircraft on the atmosphere, J. Geophys. Res., 108, 4304, doi:10.1029/2002JD002623, 2003b.

Gauss, M., Myhre, G., Pitari, G., Prather, M. J., Isaksen, I. S. A., Berntsen, T. K., Brasseur, G. P., Dentener, F. J., Derwent, R. G., Hauglustaine, D. A., Horowitz, L. W., Jacob, D. J., Johnson, M., Law, K. S., Mickley, L. J., Müller, J.-F., Plantevin, P.-H., Pyle, J. A., Rogers, H. L., Stevenson, D. S., Sundet, J. K., van Weele, M., and Wild, O.: Radiative forcing in the 21 st century due to ozone changes in the troposphere and the lower stratosphere, J. Geophys. Res., 108, 4294, doi:10.1029/2002JD002624, 2003c.

Gauss, M., Isaksen, I. S. A., Lee, D. S., and Søvde, O. A.: Impact of aircraft NOx emissions on the atmosphere - tradeoffs to reduce the impact, Atmos. Chem. Phys., 6, 1529-1548, 2006 a.

Gauss, M., Myhre, G., Isaksen, I. S. A., Grewe, V., Pitari, G., Wild, O., Collins, W. J., Dentener, F. J., Ellingsen, K., Gohar, L. K., Hauglustaine, D. A., Iachetti, D., Lamarque, J.-F., Mancini, E., Mickley, L. J., Prather, M. J., Pyle, J. A., Sanderson, M. G., Shine, K. P., Stevenson, D. S., Sudo, K., Szopa, S., and Zeng, G.: Radiative forcing since preindustrial times due to ozone change in the troposphere and the lower stratosphere, Atmos. Chem. Phys., 6, 575-599, 2006b.

Grewe, V., Dameris, M., Fichter, C., and Lee, D. S.: Impact of aircraft NOx emissions. Part 2: Effects of lowering the flight altitude, Meteorologische Zeitschrift, 11, 197-205, doi:10.1127/0941-2948/2002/0011-0197, 2002.

Grini, A., Myhre, G., Sundet, J. K., and Isaksen, I. S. A.: Modeling the annual cycle of sea salt in the global 3-D model Oslo CTM-2, J. Climate, 15, 1717-1730, doi:10.1175/15200442(2002)015; 1717:MTACOS >2.0.CO;2, 2002.

Hall, T. M. and Plumb, R. A.: Age as a diagnostic of stratospheric transport, J. Geophys. Res., 99, 1059-1070, doi:10.1029/93JD03192, 1994.

Hall, T. M., Waugh, D. W., Boering, K. A., and Plumb, R. A.: Evaluation of transport in stratospheric models, J. Geophys. Res., 104, 18 815-18 839, doi:10.1029/1999JD900226, 1999.

Hesstvedt, E., Hov, O., and Isaksen, I. S. A.: Quasi steady-state approximation in air pollution modelling: Comparison of two numerical schemes for oxidant prediction, Int. J. Chem. Kinetics, X, 971-994, 1978.

Hidalgo, H. and Crutzen, P. J.: The tropospheric and stratospheric composition perturbed by NOx emissions of high-altitude aircraft, J. Geophys. Res., 82, 5833-5866, 1977.

Holtslag, A. A. M., DeBruijn, E. I. F., and Pan, H.-L.: A High 
resolution air mass transformation model for short-range weather forecasting, Mon. Wea. Rev., 118, 1561-1575, 1990.

Isaksen, I. S. A.: The EU project TRADEOFF - Aircraft emissions: Contributions of various climate compounds to changes in composition and radiative forcing - tradeoff to reduce atmospheric impact, Project Final report, 2003.

Isaksen, I. S. A., Rognerud, B., Stordal, F., Coffey, M. T., and Mankin, W. G.: Studies of Arctic stratospheric ozone in a 2-d model including some effects of zonal asymmetries, Geophys. Res. Lett., 17, 557-560, 1990.

Isaksen, I. S. A., Zerefos, C., Kourtidis, K., Meleti, C., Dalsøren, S. B., Sundet, J. K., Grini, A., Zanis, P., and Balis, D.: Tropospheric ozone changes at unpolluted and semipolluted regions induced by stratospheric ozone changes, J. Geophys. Res., 110, D02 302, doi:10.1029/2004JD004618, 2005.

Johnson, C., Henshaw, J., and McInnes, G.: Impact of aircraft and surface emissions of nitrogen oxides on tropospheric ozone and global warming, Nature, 355, 69-71, doi:10.1038/355069a0, 1992.

Johnston, H. S.: Reduction of stratospheric ozone by nitrogen oxide catalysts from supersonic transport exhaust, Science, 173, 517522, 1971

Kawa, S. R., Anderson, J. G., Baughcum, S. L., Brock, C. A., Brune, W. H., Cohen, R. C., Kinnison, D. E., Newman, P. A., Rodriguez, J. M., Stolarski, R. S., Waugh, D., and Wofsy, S. C.: Assessment of the Effects of High-Speed Aircraft in the Stratosphere 1998, Tech. rep., NASA, nASA TP-1999-209237, 1998.

Kraabøl, A. G., Stordal, F., Konopka, P., and Knudsen, S.: The NILU aircraft plume model: A technical description, Tech. Rep. TR 4/99, Norwegian Institute for Air Research, 1999.

Kraabøl, A. G., Berntsen, T. K., Sundet, J. K., and Stordal, F.: Impacts of NOx emissions from subsonic aircraft in a global three-dimensional chemistry transport model including plume processes, J. Geophys. Res., 107, 4655, doi:10.1029/2001JD001019, 2002.

Monge-Sanz, B. M., Chipperfield, M. P., Simmons, A. J., and Uppala, S. M.: Mean age of air and transport in a CTM: Comparison of different ECMWF analyses, Geophys. Res. Lett., 34, L04801, doi:10.1029/2006GL028515, 2007.

POET report: Present and future emissions of atmospheric compounds, EU report EV K2-1999-00011, web site: http://nadir. nilu.no/poet/, 1999.
Prather, M. J.: Numerical advection by conservation of secondorder moments, J. Geophys. Res., 91, 6671-6681, 1986.

Randel, W. J., Wu, F., Oltmans, S. J., Rosenlof, K., and Nedoluha, G. E.: Interannual Changes of Stratospheric Water Vapor and Correlations with Tropical Tropopause Temperatures, J. Atmos. Sci., 61, 2133-2148, doi:10.1175/15200469(2004)061<2133:ICOSWV>2.0.CO;2, 2004.

Rogers, H. L.: SCENIC project: Scenario of aircraft Emissions and Impact studies on Chemistry and climate: Final Report, eU Project EVK2-2001-00103, 2005.

Rummukainen, M., Isaksen, I. S. A., Rognerud, B., and Stordal, F.: A global model tool for three-dimensional multiyear stratospheric chemistry simulations: Model description and first results, J. Geophys. Res., 104, 26437-26456, doi:10.1029/1999JD900407, 1999.

Schumann, U.: The impact of nitrogen oxides emissions from aircraft upon the atmosphere at flight altitudes - results from the aeronox project, Atmos. Environ., 31, 1723-1733, doi:10.1016/S1352-2310(96)00326-3, 1997.

Stolarski, R. S., Baughcum, S. L., Brune, W. H., Douglass, A. R., Fahey, D. W., Friedl, R. R., Liu, S. C., Plumb, R. A., Poole, L. R., and Wesoky, H. L.: The 1995 scientific assessment of the atmospheric effects of stratospheric aircraft, Tech. rep., NASA, nASA Technical Report, NASA-RP-1381, 1995.

Stordal, F., Isaksen, I. S. A., and Horntvedt, K.: A diabatic circulation two-dimensional model with photochemistry: Simulations of ozone and long-lived tracers with surface sources, J. Geophys. Res., 90, 5757-5776, 1985.

Thomason, L. W., Poole, L. R., and Deshler, T.: A global climatology of stratospheric aerosol surface area density deduced from Stratospheric Aerosol and Gas Experiment II measurements: 1984-1994, J. Geophys. Res., 102, 8967-8976, doi:10.1029/96JD02962, 1997.

Tiedke, M.: A Comprehensive Mass Flux Scheme for Cumulus Parameterisation on Large Scale Models, Mon. Wea. Rev., 117, 1779-1800, 1989.

World Meteorological Organization: Scientific assessment of ozone depletion: 2002., World Meteorological Organization: Global ozone research and monitoring project - Report 47, 498 pp, Geneva, Switzerland, 2003. 